\title{
The denial of limits and interior aspects of descent
}

\author{
Richard A. Slaughter
}

Richard A. Slaughter is a Director at Foresight International, Brisbane, Australia.
(C) Richard A. Slaughter

The author would like to acknowledge referee input and, especially, the rich productive dialogue with Josh Floyd that occurred during the writing of this paper and helped shape its final form.

\begin{abstract}
Purpose - The purposes of this paper are as follows. Part one examines the role of denialism in the context of proposals advanced through the much-abused Limits to Growth (LtG) project. Part two uses three sets of criteria (domains of reality, worldviews and values) to characterise some of the interior human and social aspects of the "denial machine." It uses these criteria to address some vital, but currently under-appreciated "interior" aspects of descent. (N.B. A succinct "primer" or overview of the concept and underpinning rationale for notions of "descent pathways" is provided in the introduction to this special issue.)
\end{abstract}

Design/methodology/approach - The paper draws on a number of authoritative sources that track the dimensions of global change and, specifically, the ways that humanity is tracking towards Dystopian overshoot-and-collapse futures. The significance of the $L t G$ project is assessed in this context. Part two employs the criteria noted above to identify and open out the centrality of the human and cultural interiors.

Findings - Responses to the LtG project are shown to have deprived humanity of the clarity and will to respond effectively to the emerging global emergency. The rise of climate change denialism has followed suit and made effective responses increasingly difficult. A new focus, however, on some of the dynamics of reality domains, worldviews and values, clarifies both the nature of the problem and prefigures a range of solutions, some of which are briefly outlined.

Research limitations/implications - This is primarily a conceptual paper that suggests a range of practical responses. For example, re-purposing parts of the current information technology (IT) infrastructure away from financial and economic indices to those tracking the health of the planet. Also translating the case put forward here for a new generation of Institutions of Foresight (IoFs) into real-world start-ups and examples. Further research is needed into the uses and limitations both of positive and negative views of futures. It is suggested that the latter have more value than is commonly realised.

Practical implications - In addition to those stated above, the practical implications include new uses for IT infrastructure based on worldcentric - rather than financial and economic worldviews; designing and implementing a new generation of loFs; and finding new ways to inform the public of impending Dystopian outcomes without exacerbating avoidance and depression.

Social implications - The social implications are profound. Currently, humanity has allowed itself to "tune out" and ignore many of the well-founded "signals" (from the global system) and warnings (from those who have observed and tracked real-world changes). As a result, it has outgrown the capacity of the planet to support the current population, let alone the 10 billion currently projected by the United Nations (UN). Something must give. Applied foresight can provide essential lead time to act before human actions are overwhelmed by forces beyond its control.

Originality/value - The paper draws together material from hitherto disparate sources to assess the $L t G$ project. It also deploys key concepts from an integral perspective that shed new light on human and cultural forces that determine how people respond to the prospect of Dystopian futures. In so doing, it provides insight into why we are where we are and also into some of the means by which humanity can respond. Specifically, it suggests a shift from collapse narratives to those of descent.

Keywords Limits to growth, Denialism, Descent pathways, Global emergency, Human and cultural interiors, Trajectory of development

Paper type Conceptual paper 
The key question of our era is which complex system will tip first, the climate or the human response (Berners Lee \& Clarke, The Burning Question, 2013).

Go, go, go, said the bird: human kind cannot bear very much reality (T.S. Eliot, Burnt Norton, 1935)

\section{Introduction}

The emergence and success of denialism during the latter part of the 20th century has created a number of obstacles, or roadblocks, that seriously impede many of the "adaptive changes" that need to be made. For example, attempts to reduce reliance on fossil fuels and rein in $\mathrm{CO}_{2}$ emissions. Denialism has thus made attempts to respond to the global emergency that much more difficult. It has also become clear that the Limits to Growth (LtG) narrative that developed over some four decades had a great deal more to offer humanity than the latter was ready or willing to receive. In essence, it provided opportunities to come to grips with some of the cascading consequences of its own actions. That is, to take responsibility for the dilemmas created by its over-rapid, and largely unchecked, expansion and growth. But, unfortunately, most of these opportunities, along with uncountable "missed signals" and "paths not taken," were - and remain - overwhelmed by other, much more powerful, social and economic forces. As a result, it is no longer unthinkable to anticipate the collapse of the global economy and with it that of societies that have come to depend so heavily on it. Indeed, the weight of available evidence now points in exactly that direction (Ahmed, 2014; Watts and Viera, 2014; Ehrich and Ehrlich, 2013).

As suggested in The Biggest Wake-Up Call in History (BWCH) notions of "collapse," however, even when they are brought to full awareness, are widely misunderstood and feared (Slaughter, 2010; 2012a; Scranton, 2013). Yet the time has long passed when such responses can remain unquestioned. Rather, we need to understand and respond to dangers and the unavoidable disruptions that will occur (Poyourow, 2014). One way to begin involves shifting from despairing narratives of "collapse" to what are arguably more useful and desirable notions of "descent." Indeed, it is legitimate to suggest that a great deal of constructive social and symbolic power may well reside in that one shift of emphasis and understanding alone. Another is to redefine what we mean by "futures literacy" and seek its wider application in mainstream social contexts.

Once we begin to consider descent pathways (which is, of course, the focus of this special issue of Foresight) in all their richness and plurality, we realise that, far from being helpless victims of an approaching inevitable global crash, humanity has access to a wider range of options than that currently under consideration (Zolli and Healy, 2012). The drawback, thus far, is that many of these options have barely registered in mainstream social (political, economic and organisational) consciousness. This is arguably the greatest obstacle facing us today. What the informed public is slowly becoming more aware of are the early impacts of two symptoms of an impending global crisis - the dawning reality of peak oil and the early signs of climate disruption (previously known as global warming). Yet, as noted, how to respond is, for many, both uncertain and problematic. It is then all-too-easy to simply avert one's gaze and carry on as if nothing much was at stake. Furthermore, some powerful and well-resourced entities continue to muddy the waters still further. They persist in importing 20th century denialism into a context within which it flies in the face of reality and has become openly delusional (Wood, 2006; Weisman, 2013). This is no longer acceptable. Hence, a new, or renewed, agenda for futures and foresight work is essential.

\section{Part one: origins and consequences of the "denial machine"}

The origins of denial are both ancient and, rather unfortunately, deeply embedded in human nature. Cassandra's dilemma - the notion that insights into the future have value, but people will often refuse them - remains evident two or more millennia later (AtKisson, 1999). This is both understandable and, in current conditions, contradictory. Why? Understandable because we 
know that certainty and danger always seem to diminish as we move away from the present. Contradictory because if we fail to develop and apply our full capabilities for intelligent and timely foresight, then the collapse of civilisation becomes inevitable.

Denial is supported by the common human practice of future discounting. Simply put this is the notion that "a dollar today is worth more than a dollar tomorrow, next week or next year." The fate of human civilisation is now linked directly and substantively with our ability to counter denial and future discounting. Yet we seldom bring to awareness the interior human and cultural factors from which they spring. Both responses allow a large number of people to ignore and avoid the many "signals of change" that have emerged, and are emerging, both from human reflections on the global emergency (books, papers and scientific reports) and from the signals themselves that originate within the global system and, hence, are directly experienced (more powerful storms, melting ice sheets, dying reefs, rising sea levels, mass migrations, etc.). T.S. Eliot's insight that "human kind cannot bear very much reality" then begins to look less like a poetic comment than a profoundly ironic epitaph (Hamilton, 2010).

If these two increasingly problematic modalities of human psychology (i.e. denial and discounting) were merely that, we would not be in such a deep hole, so to speak. But something else occurred from the early 1960s that boosted these tendencies and ramped them up into something quite new and dangerous. The story has been told in a number of places but perhaps most clearly and cogently in a well-researched book called Merchants of Doubt (Oreskes and Conway, 2011). It provides a detailed account of how organised opposition to Rachael Carson's work on the effects of dichlorodiphenyltrichloroethane (DDT) in Silent Spring morphed into a full-on attack not only on her but also, subsequently, on others who were involved in researching a range of environmental issues. These included acid rain, ozone depletion, the effects of smoking and, more latterly, climate disruption.

Within the USA, a number of powerful individuals and corporations sought to protect their own strictly limited interests by underwriting a series of initiatives designed to propagate an enterprise of unparalleled negativity. One of many egregious examples is that of ExxonMobil which "initiated forty-three different front organisations to create the illusion of widespread doubt about whether global warming was really occurring" (Urry, 2013, p. 85). The defining proposition throughout was, and remains, one of quite staggering cynicism the notion that "doubt is our product." Using every means at its disposal, this alliance of conservative institutes, think tanks, media agencies and well-off individuals sought to delay, deny, confuse, dilute and, where possible, destroy the work and reputations of those who'd attempted to understand and deal with emerging issues that concern everyone, or should do so. There can be few prior initiatives that are more self-defeating and damaging to our species than this. For they have had, and continue to have, pervasive effects around the world. In the USA, public opinion in support of environmental protection has been declining for a couple of decades (Miller and Hopkins, 2013).

Half a century after the attacks on Carson and other scientists, the denial machine is more powerful and better resourced than ever. Therefore, it's worth summarising some of the most recent evidence, both for the current scale of these interventions and also some of their specific effects. Suzanne Goldenberg writes that:

Conservative billionaires used a secretive funding route to channel nearly $\$ 120 \mathrm{~m}(£ 77 \mathrm{~m})$ to more than 100 groups casting doubt about the science behind climate change, the Guardian has learned. The funds, doled out between 2002 and 2010, helped build a vast network of think tanks and activist groups working to a single purpose: to redefine climate change from neutral scientific fact to a highly polarising "wedge issue" for hardcore conservatives.

Then, regarding consequences, she adds that:

By 2010 , the dark money amounted to $\$ 118$ m distributed to 102 think tanks or action groups which have a record of denying the existence of a human factor in climate change, or opposing environmental regulations. The money flowed to Washington think tanks embedded in Republican party politics, obscure policy forums in Alaska and Tennessee, contrarian scientists 
at Harvard and lesser institutions, even to buy up DVDs of a film attacking Al Gore. The ready stream of cash set off a conservative backlash against Barack Obama's environmental agenda that wrecked any chance of Congress taking action on climate change. Those same groups are now mobilising against Obama's efforts to act on climate change in his second term (Goldenberg, 2013, emphasis added)

The conclusion here is unambiguous. Set against those who, like Gore himself, Bill Gates, and other philanthropists who devote much of their time, energy and wealth to useful causes, there are other equally well-endowed people and organisations that have, for reasons of their own, opted to do exactly the opposite. Where we need clarity and collective purpose, they sow confusion and division. Where we need action and political courage, they sow doubt and fear. While more recently Obama has taken new steps to rein in $\mathrm{CO}_{2}$ emissions by US power plants, valuable time to undertake broader society-wide initiatives has been lost. By elevating its own immediate short-term sectional interests above all others, the "denial machine" has rendered an already difficult situation that much more intractable. It is entirely possible that, in time, activities of this kind may come to be regarded as crimes against humanity.

\section{Denial and global limits}

The denial of global limits also has ancient roots, one of which is a cornucopian view of nature. The "horn of plenty" of ancient times, or its equivalent, has been represented countless times in the arts of many cultures across the centuries. Although now less overtly common than it was, echoes of this earlier view of nature as being "vast and inexhaustible" arguably stand behind and support the common assumptions of many people, especially growth-oriented corporate and political leaders. Of course, it never was exactly like that. Droughts, famines and many types of natural catastrophe reminded people time and again that nature was always more liable to sudden and drastic variations than ever suited populations of human beings. But, nevertheless, kingdoms and empires could rise and fall without having much more than local or regional effects - at least as far as could be seen and understood at the time. One ecosystem might collapse, but there was usually another that could be reached and exploited by a brave or fortunate few who could begin again (Flannery, 1994; Diamond, 1998).

Although such times have long passed and humanity is now more like a multi-hued garment wrapped around the world, compressing it ever more tightly, remnants of those earlier views arguably continue to support the easy accommodation of everyday rapaciousness and the never-ending pursuit of economic growth (Weisman, 2013). Fused with these are other myths of human power and agency - myths that drew new life from the discoveries of the enlightenment, the applied technologies of the industrial revolution and now the apparently irresistible rise of IT. Much comfort could be, was, and is, derived from such anthropomorphic tendencies. But now and then, rare individuals have occasionally developed the capacity to see through the myths and diversions of their age. They see things "as they are," at least for a while. Significant among these in this context is Lewis Mumford. His account of "the removal of limits" resonates powerfully today and, in so doing, helps us to appreciate some of the driving forces that continue to operate below the surface of our present psychic landscape.

Here, for example, is Mumford writing on this very topic only a few short years after the publication of Silent Spring:

The new industrial complex is based on a group of postulates so self-evident to those who have produced the system that they are rarely criticised or challenged - indeed almost never examined - for they are completely identified with the "new way of life."

First: man has only one all-important mission in life: to conquer nature ....(This) is in effect to remove all natural barriers and human norms and to substitute artificial, fabricated equivalents for natural processes: to replace the immense variety of resources offered by nature by more uniform, constantly available products spewed forth by the machine.

PAGE 530 foresight $\mid$ VOL. 16 NO. 62014 
From these general postulates, a series of subsidiary ones are derived; there is only one efficient speed, faster; only one attractive destination, farther away; only one desirable size, bigger; and only one rational quantitative goal, more.

He then added that:

On these assumptions, the object of human life, and therefore of the whole productive mechanism, is to remove limits, to hasten the pace of change, to smooth out seasonal rhythms and reduce regional contrasts - in fine, to promote mechanical novelty and destroy organic continuity (Mumford, 1971, p. 173, Emphases added).

What Mumford achieved nearly half a century ago was to remind us of an underlying reality that had almost vanished from individual and collective memory. That is, the sheer globe-spanning abnormality of the times we live in, the enormous gulf that separates what we take to be normal from all previous places and times.

While deniers of every stripe find new ways to block out this underlying reality, the generic "hockey stick" graph popularised by Al Gore (and deplored by his critics) shows how countless human activities have, over recent decades exerted many new pressures and effects on the world: from atmosphere to soils, from oceans to forests and from reefs to many other species edging closer to extinction. This generic graph, repeated many times over, also records how these collective impacts now occur on scales that, in previous times, were only achieved by nature itself. Yet despite the fact that they have been repeatedly verified, these uncomfortable new realities continue to be denied and put out of sight (Steffen et al., 2004; Emmott, 2013). Those driving the denial machine are, by and large, unconcerned. In the West, they are insulated by their current wealth and are far more interested in the dynamics of currency speculation, the manipulation of financial derivatives and the pursuit of material affluence than they are in the health of the global system that makes their own and other life possible. More recently, a new and deeply concerning twist has been added to this story: the "gaming" of stock exchanges by the strategic use of technically sophisticated high-speed trading algorithms (Smith, 2014).

A further factor here - and one that has also received less attention than perhaps it should is the shifting baseline of human experience and knowledge. Each generation grows up in a world that seems, in some sense, "natural" to it. What existed in earlier times has changed or disappeared. As such, it is unlikely to be valued or missed. What exists now is "normal', the way things are. The fact that this "baseline" is updated and reconstituted from generation to generation serves to rob human beings of a reliable and authoritative historical perspective. Unless, that is, conscious efforts are made to restore it. In some places, however, selective cultural amnesia is adopted as official policy. The process of "forgetting" what has been lost to achieve "progress" in the present can be seen most dramatically, perhaps, in China. Here, the environment has been sacrificed in pursuit of development and growth. The penchant for this kind of growth and for ignoring limits in China has undoubtedly been inherited from the West. But now, coming so much later, the consequences are proving that much more disastrous (Simons, 2013).

\section{Responses to the $L t G$ project}

Oreskes and Conway showed in some detail just how the "merchants of doubt" were able to delay or undermine a number of significant social initiatives, each of which were attempting to come to grips with some of the costs of "progress." There is, however, a parallel story that has similar features, including an equally strong bearing on our present dilemma. I refer, of course, to the LtG project that began in the early 1970s and ran for nearly four decades. The project is summarised and framed by four key works:

1. The Limits to Growth (Meadows et al., 1972);

2. Beyond the Limits (Meadows et al., 1992); 
3. Limits to Growth - the 30-Year Update (Meadows et al., 2005); and

4. 2052 - A Global Forecast for the Next Forty Years (Randers, 2012).

The focus here is less on the content of these works, significant as that is, than on the reception accorded to the project over this time. Its key proposals for adapting to a rapidly changing and increasingly threatened world are readily summarised. They included:

- Slow and eventually stop population and capital growth;

- in preference to harsh experience, employ the tools of anticipation in decision-making;

- reduce the throughputs of energy and materials, in part through using capital more efficiently;

- conserve the sources and sinks of materials used by humans;

- slow down and eventually reverse soil erosion;

- detect, understand and respond more quickly to signals of change; and

- overall, look further ahead so that actions and decisions can be made on the basis of informed views of long-term costs and benefits. (Meadows et al., 2005)

It is a sad comment on our times that most of these suggestions failed to gain any significant mainstream traction except, perhaps, for the third item dealing with resource conservation. In recent years, however, a number of observers have subjected the LtG project to rigorous review. The most thorough and detailed treatment is undoubtedly that by Italian scholar Bardi (2011). He shows how, from the outset, reactions were distinctly polarised. For example, observers from within the scientific community were "impressed by the width and depth of the studies, by the innovative approach and by the use of computers; at that time, a novelty" (Bardi, 2011, p. 49). Many others, however, were hostile and dismissive. Economists appeared to have taken particular offence. One group simply considered it "too pessimistic." Others went further and labelled it a "brazen, impudent piece of nonsense" and "irresponsible nonsense." Then, under the heading of "Models of doom" a group of academics at a British university critiqued the project not only for its "pessimism" but also for "fundamental faults" in the model that the researchers had used (Bardi, 2011, pp. 49-62).

Similar points were made by a variety of critics over time. Yet one of the key features that most failed to appreciate was that, as the project evolved, the researchers showed every sign of listening, learning and adapting their methodology and approach. This "capacity to learn" is clearly visible in each of the later books. But by then, the weight of negative publicity meant that, by and large, few mainstream actors were listening. The "message" had been "tuned out," set aside and largely forgotten. Without further research, we cannot be sure of the extent to which an organised campaign of subversion took place. What we can be sure of, however, is that the dominant "growthist" worldview had enormous influence - and still does. Virtually nobody holding that view wanted to know about limits, reducing growth, thinking long-term or establishing high-quality Institutions of Foresight (IoFs). Instead, as had happened before, those driving the economic machine only wanted to know how to keep it tethered to the dictates of "faster, further away, bigger and more." No one wanted to face up to the contradictions inevitably created by infinite growth within a finite system.

Bardi completes his detailed review of some of the more substantial criticisms of the LtG project in the following way. He writes that:

Reviewing the debate on the 1972 LtG study as it was conducted up to the last flare up in 1992, the general impression is that it (i.e. the debate) was incomplete; that is, it had never really faced the questions that had been posed at the beginning. In most cases, criticism was based on a hasty and partial reading of the study, while some of the best known refutations of LtG [. . .] had been based on an incomplete understanding of what system dynamics is and what it attempts to do (Bardi, 2011 p. 62). 
Another researcher who examined the project in some detail is Graham Turner, a scientist from Australia's premier scientific organisation, the Commonwealth Scientific and Industrial Research Organisation (CSIRO). Although his report is fairly technical, his comments on the nature of the response to the LtG are unambiguous. They also reinforce those made by Bardi. He writes that:

From the time of its publication to contemporary times the LtG has provoked many criticisms which falsely claim that the LtG predicted resources would be depleted and the world system would collapse by the end of the 20th Century. Such claims occur across a range of publication and media types, including scientific peer reviewed journals, books, educational material, national newspaper and magazine articles, and websites. (But) this paper shows them to be false (Turner, 2008/2009, pp. 2, 9 \&13).

This is directly relevant because it is precisely here in the reception accorded to the LtG that some of the ways a dominant reality responds to initiatives that challenge it are most clearly revealed. More startling, perhaps, even than this is that Turner's comparison of the original scenarios with subsequent data also revealed that there was a surprisingly good correlation between what had been termed the "standard run" scenario and the real-world of the early 21 st century. He comments that "if there were fundamental flaws in the World3 model then scenario outputs from the model would be unlikely to match the long time-series data as well as they do." Furthermore:

[...] the good comparison of scenario outputs with historical data provides a degree of validation of the World3 model, and emphasises the likelihood of the global system reproducing the underlying dynamics of the 'standard run' scenario (Turner, 2008/2009, p. 34).

Some of the details of the latter also closely matched other emerging issues such as those of peak oil and constraints on food production in some areas. However, the sting, as it were, is in the tail for Turner then concluded that:

The observed historical data for 1970-2000 most closely matches the simulated results of the LtG 'standard run' scenario for almost all the outputs reported; this scenario results in global collapse before the middle of the century.' (Turner, 2008/2009, p. 37).

Finally, he added that:

The data comparison presented here lends support to the conclusion from the LtG that the global system is on an unsustainable trajectory unless there is a substantial and rapid reduction in consumptive behaviour, in combination with technical progress (Turner, 2008/2009, p. 38).

Bardi's and Turner's work on LtG should not be seen in isolation. It has also been substantiated by other, more empirically based, work. For example, in 2009 Johan Rockstrom, director of the Stockholm Environment Institute, Sweden, convened a meeting of specialists to take a fresh look at human impacts on the global system. This time the focus was on nine interlinked planetary boundaries and the thresholds associated with each. The research team found that planetary boundaries had already been exceeded in three cases (climate change, species extinctions and the nitrogen cycle), that four more were close to being breached (ozone depletion, fresh water usage, ocean acidification and changes in land use). At the time, there was insufficient data to decide on the remaining two (atmospheric aerosol loading and chemical pollution) (Rockstrom, 2009). Results of this kind clearly support both the conclusions of the LtG project and the view that major shifts are under way in the global environment that can no longer be ignored.

Sadly, however, denialism continues to impede coherent and useful responses. For example, Australia's current intention to further expand coal mining in sensitive areas and export it through the Great Barrier Reef provides a clear example of embedded short-termism and avoidance. The whole process certainly provides current income but at the expense of limiting $\mathrm{CO}_{2}$ emissions here and overseas (McKibben, 2013; Pearse et al., 2013; Spratt, 2014). Similarly, at the time of writing, a newly elected Liberal government is taking active steps to abolish the carbon tax. It has already withdrawn funding from the Climate Commission (which then found other sources of income) and abolished the Green Energy Corporation. A couple of 
examples of this diminished outlook on the part of conservative news media similarly show how the earlier worldview still permeates social consciousness. In 2012, the Australian newspaper published without any comment an article headed "Death of a Mumbai river will not trouble many." Near the end of the piece, the following passage appeared:

The trouble with the Mithi (river) is that other than when it overflows during a downpour, it would have little or no bearing on most Mumbaikars' lives were it to disappear tomorrow. It provides no water to the city. Sure, an entire ecosystem would die out, but when has that ever been cause for alarm? Its only function is as an unwitting conduit for flushing sewerage out to sea (Kilachand, 2012, emphasis added).

Few editors with any real understanding of the wider global context could credibly allow a piece like this to cross their desk and be published without comment. But there it was: further evidence that, in this view, the environment is dispensible, its decline is "no cause for alarm." Silent Spring the LtG project and, indeed, the entire literary and scientific corpus of environmental literature and research might as well have never existed. Then, in July 2013, a piece appeared in the financial section of the same paper under a picture of a hot air balloon over the New Zealand South Island. The heading was "Kiwis" 2060 forecast seen as a load of hot air' (Howard, 2013). As the title indicates, the article was mockingly dismissive of any attempt to engage in long-term thinking. In fact, it portrayed the whole exercise as a complete waste of time. So much for the disciplines of high-quality futures work and applied foresight. From within a conservative, here-and-now, econometric, future-discounting and market-focused outlook the peremptory dismissal of forward thinking is clearly alive and well.

\section{The trajectory of development and the "carbon complex"}

It is well-known that hindsight can usefully inform foresight. Therefore, a view back over the past 50-100 years helps unite many of these factors within a coherent and common perspective. In so doing, it sheds further light on how evasion and denial have not only helped shape modern history but also to determine the dominant trajectory, or direction, of development across the globe. At issue here, of course, is not the conventional and passive view that simply notes "what happened." Critical thinking, depth perception and careful discrimination - the very capabilities that seem to be so rare in politics and the popular media - are necessary to discern meaningful patterns and ask questions that matter.

The present "trajectory of development" that characterised the "American century" has neither produced a stable world nor fulfilled previous hopes for positive futures. It has neither led to durable peace nor sustainable prosperity (other than perhaps for a currently fortunate few). What it has led to is a "sixth extinction" currently decimating the natural world and what's been termed the "double whammy" of peak oil and global warming/disruption. Unfortunately, these "heavy trends" are now so well-established that they can no longer be dismissed as mere variables in the forward view. They look increasingly like fundamental determinants (Hansen, 2012; Jamail, 2013). While this remains news to entities such as the US Congress and the National Intelligence Council (NIC), it has become clear to others that this very developmental trajectory has closed-off options that had previously been available (Urry, 2013; Slaughter, 2013b).

We need to bear in mind here that there was nothing inevitable about this trajectory or, indeed, its current outcomes. It was maintained by a series of deliberate policies and decisions in spite of the fact that there have been countless chances to modify it and repeated chances to branch out in other directions and activate other options. Two examples can be briefly mentioned. One is the opportunity created by the environmental movement of the 1970s to rein in economic growth, re-value the environment and bring the economy into a more sustainable and balanced relationship with it. Another was inherent in two pivotal broadcasts to the American nation made by then president Jimmy Carter in 1977 and 1979 in which he warned of the dangers of the path the USA was then set upon (Carter, 1977, 1979). Unfortunately, his attempts to lead the nation down a different pathway towards a different future were rejected. Instead, the American people chose to

PAGE 534 |foresight $\mid$ VOL. 16 NO. 62014 
"continue the party," as it were, that is, the orgy of over-consumption and careless use of resources, especially oil (Bageant, 2011; Slaughter, 2010, op. cit. chapter 2).

Similarly, instead of taking advantage of the many opportunities provided to fashion longer-term views and adopt a more cautious and conserving mode of development, we saw above how powerful forces in the USA adopted a very different strategy: they sought to marginalise or destroy them. Writing from a sociological perspective, John Urry draws our attention to the way that US corporations "developed during the 1980s a 'counter-activism' against environmentalism and brought about a virtual moratorium on new environmental legislation, as well as reversing other USA environmental regulations" (Urry, 2013, p. 83). This led, in turn, to what he calls "a more integrated 'carbon complex' in the USA that has shaped the world to its own interests from 1970 onwards." He writes that it "deployed many tactics to keep acquiring the 'foreign oil' so essential to the high-carbon American way of life" (Urry, 2013, p. 86). Urry identifies four strategies that he argues facilitated this process. The USA:

- imposed the doctrine of "free trade" whenever it suited its interests;

- used (the World Bank, the International Monetary Fund and the World Trade Organisation) "to promote and help fund various exploration and pipeline developments in poorer parts of the world";

- developed a significant number of client states in the Persian Gulf; and

- mandated the Central Intelligence Agency $(C I A)$ to engage in "covert regime destabilisation" (Urry, 2013, pp. 86-8).

This kind of analysis will not appeal to US patriots, but it does not stand in isolation. It is reinforced by others - for example, that produced by a former US agent who had actually participated in the process and came to realise what was at stake (Perkins, 2004; Hiatt, 2007). The USA had been the first developed nation, after Germany perhaps, to pioneer the technology of oil extraction and processing. It certainly pioneered the kind obsessive and intrusive marketing techniques that have infiltrated virtually all media around the world. It set about constructing a way of life that broke with the past and, as is becoming more clear with each passing year, with the future also. The private car became the universal symbol and icon of a rising and then-powerful America. Urry again relates this back to "carbon capital." He writes that the interests it represented were:

[. . . ] able to get widely accepted the notion that roads are good for business; they are natural and necessary to a modern economy and society. The car and oil lobby created the idea that roads are "needed" and that taxation should be used to pay for them. Over the 20th century cities and suburbs became monopolised by cars, which took over most road space and city environments (Urry, 2013, p. 79).

We now know, of course, that this mode and trajectory of development was, in effect, a rush towards mass addiction the side effects and consequences of which would become ever more damaging. In retrospect, it's also clear that "the very last thing that should have been done with this oil was to burn it up in powering cars, trucks, trains, ships and planes" (Urry, 2013 , p. 8). At the time, however, there was so much money to be made that "the future," despite a multitude of popular treatments and diversions on TV and in film, was a subject of little or no concern to those driving the system. China is the new game changer and is powering ahead with its own version of the Western model. Now, however, we are much closer to global limits than ever before and no one is in a position to say how or when China's development will be reined in to accommodate them (Simons, 2013).

\section{Species characteristics in a darkening world}

It is appropriate to pause at this point, however, and recognise that there is more at play here than the mistakes, oversights and dysfunctions that have played, or are playing, out within any particular nation. It is both too easy and self-serving to merely demonise the USA and China as the bad "others." Doing so simply allows us to project upon them those aspects of ourselves that we do not 
wish, or are not ready, to acknowledge and accept. That could include our greed, self-regard and frequently careless participation in ways of life that we know to be damaging. It follows that standing behind the global emergency is something far older and more primal.

In the final analysis, what we are dealing with here are long-standing expressions of species characteristics, as they are manifested through various social and cultural frameworks. This is a topic that has been almost universally overlooked within most of the debates and literature that focus on aspects of the global emergency. It is made explicit, however, in the following quote from E.O. Wilson who asserted a decade ago that:

[...] we have entered the century of the environment, in which the immediate future is usefully conceived as a bottleneck. Science and technology, combined with a lack of self-understanding and a Paleolithic obstinacy, brought us to where we are today. Now science and technology, combined with foresight and moral courage, must see us through the bottleneck and out (Wilson, 2002, p. 23).

It is notable that Wilson's view includes internal and external factors. Science and technology are important - but then so too is human "obstinacy" and the quality of self-understanding that must deal with the "Century of the Environment." I've long considered that "science + technology + foresight + moral courage" provides a superbly compressed summary of the essential core requirements that are called into play as we confront the global emergency.

We should also acknowledge that from the post-war "baby boom" generation onward, the rich West - and those who have sought to emulate it - benefitted enormously both from the wealth released by US-driven hyper-development and, indeed, many - but by no means all - of the products and services that have accompanied this process. Yet overall the benefits have only flowed up to a point, after which many of them arguably became counter-productive or worse (e.g. smoking, obesity, compulsive consumption, social anomie and alienation from natural process). We also know that human happiness does not continue to increase once a moderate level of affluence is attained. Furthermore, structural inequality also imposes its own penalties (Hamilton, 2005; Wilkinson and Pickett, 2009).

Perhaps the most challenging fact that we must face today is that humanity as a whole is in less than adequate shape to acknowledge, and understand the need for, strategies to see it through the emerging crisis. Although major wars between states have subsided the Arab Spring has morphed into one of several complex and intractable conflicts. Besides these, many divisive issues and concerns continue to deprive humanity of the energy, good will and creativity it needs for longer-term survival. Organised crime flourishes while global governance is a mess (Glenny, 2009). Weapons of mass destruction remain ever-present threats. The race for resources intensifies while the natural world reels under multiple impacts. Compulsive marketing and merchandising show no signs of abating. Finally, the much-heralded IT revolution and the rapid growth of the Internet that were once seen as enabling and productive innovations are becoming ever more ambiguous. It seems to me that they are changing into something far darker, more subversive, than had ever been envisaged by the early pioneers (Lanier, 2013; Taylor, 2014).

A regular diet of this kind of "bad news" at conscious and sub-conscious levels is, I think, a major reason why so many people turn away and withdraw to the privacy of their (mostly) comfortable, high-tech equipped home environments. However, there is clearly something that does not ring true in this account. If this were the only way of regarding the present and future there would be little point in writing (or reading) about either. Therefore, it's central to the thesis presented here that what are wrongly described as "gloom and doom" responses, while common, are neither the best nor the only options. Rather, I want to suggest that Dystopian futures be regarded less as a reason for depression and disengagement than as provocations that invite us to revise how we frame and interpret our current reality and the dilemmas it holds before us (Scruton, 2013: Slaughter, 2013a). To

PAGE $536 \mid$ foresight $\mid$ VOL. 16 NO. 62014 
achieve this, we need to move from conventional and exterior responses to post-conventional ones that are also informed by insight into the human and social interiors.

\section{Part two: global issues and developmental realities}

In earlier work, I drew on concepts from an Integral perspective seeking to look with "fresh eyes" on global warming, peak oil and the transgression of global limits (Slaughter, 2010; 2012a). I then explored some of the ways forward that I felt held out greatest promise for resolving them and prefiguring more humanly desirable, liveable futures. During that process, I came to regard underlying issues of perception, understanding and value as among the primary impediments facing humanity.

We know that there's a profound disconnect between, on the one hand, reliable knowledge about the global emergency and, on the other, what might be called the applied capacity to respond. It is reported constantly in the quality news media (Holmes, 2013). Then, as multiple "scanning hits" in the form of news reports, government statements, scientific reports and, indeed, a range of futures-related literature, continued to accumulate, this impression has been repeatedly confirmed. If we are to have any hope of making headway with these challenging issues, we will, indeed, have to change the terms of the debate.

In work of this kind, there's no "one size fits all." No two individuals will, or can be expected, to see things in identical ways. Therefore, we need ways of cutting through the complexity while, at the same time, employing objective criteria that do justice to some of the variables involved. Quadrants, worldviews and values are summarised as follows:

- The quadrants (or "windows" on reality):

- The upper-left quadrant (the interior "world" of human identity and self-reference);

- The lower-left quadrant (the interior "world" of cultural identity and knowledge);

- The upper-right quadrant (the exterior "world" of individual existence and behavior);

- $\quad$ The lower-right quadrant (the exterior world and physical universe).

- Levels of worldview complexity

- Pre-conventional (survival and self-protection);

- Conventional (socialised, passive and adherence to status quo);

- Post-conventional (reflexive and open to complexity and change); and

- Integral (holistic, systemic, values all contributions, works across boundaries, disciplines and cultures).

- Value levels

- Red (egocentric and exploitative);

- Amber (absolutist and authoritarian);

- Orange (multiplistic and strategic);

- Green (relativistic and consensual);

- Teal (systemic and integral); and

- Turquoise (holistic and ecological).

They by no means exhaust those that are available. In this short paper, however, their purpose is to indicate the potential of this broad line of enquiry. They emerge from a four-quadrant view of reality, four levels of worldview complexity and six value levels.

It must be stressed that to understand use these concepts successfully, it is vital to consult original sources and to become familiar their uses and limitations (Wilber, 2000; 
Esbjorn-Hargens, 2009). That said, I will first summarise some implications of the failure to use such concepts or their equivalents.

Perhaps, the most obvious problem I see in many attempts to address global issues is what has been termed (somewhat disparagingly at times) a "flatland" view. That is, a view in which the range of crucial "vertical" distinctions that characterise so many aspects of reality (as in Items 2 and 3 above) are simply overlooked. Because individual and social reality cannot really be described or understood in their absence, the failure to use them critically and carefully vitiates attempts to make useful statements about either. A great deal of work that deals with futures - both in fiction and non-fiction - suffers from this structural defect. As noted above, it is even absent in high-end projects such as the latest US National Intelligence Council Report (NIC, 2013; Slaughter, 2013c). These oversights or omissions can also be seen in contemporary Utopian writing where the writer, driven by an authentic need to create positive images of more desirable futures, draws on earlier and simpler notions of self and society. He or she is then faced with the task of attempting to "wrestle" their fictional characters into the shapes and behaviours seemingly required within simpler and more sustainable societies. However, in lacking depth insight into the human and cultural interiors, most such attempts remain unconvincing (Slaughter, 2013b).

A related oversight can be seen when efforts to address issues are directed overwhelmingly toward the external collective domain (or lower right quadrant). That is, issues of resources, technology, infrastructures, the retrofitting of cities and so on. It is not that these are unimportant - far from it. The present assault on nature is occurring in exactly that arena. The difficulty is that a strong focus on this domain provides a drastically incomplete mind picture of the world. It leaves out the sources, root causes or "drivers" of the very phenomena that emerge later in various forms of human suffering and environmental degradation. In integral terms, a near-exclusive focus on phenomena in any single quadrant arena is known as "quadrant absolutism." That is, making that view, and related phenomena too central, too important.

The motivating and inhibiting power of values and value-based operating systems have been shown to permeate everything that people do and, by extension, how societies live and evolve. Yet despite their centrality, these powerful interior realities are seldom considered explicitly. The good news is that greatly improved insights into these developmental factors have emerged from numerous credible sources over the last century or so (Wilber, 2000; Beck and Cowan, 1996; Walsh, 2012). The resulting insights are now part of the necessary background for understanding human and social existence. The crucial point is that bringing some of these insights into play in the present context changes everything. This is so because we are no longer dealing with monolithic and over-simplified generalities but with more of the depth, diversity and variety of human and cultural life-worlds. It follows that it is to a considerable extent here, in the interior realms of human and social existence that the most promising seeds of liveable futures may be found (Slaughter, 2012b).

\section{Interior development and descent pathways}

There's little doubt that the present trajectory of development implies widespread disruptions in the near future, perhaps to be followed by a wider collapse of civilisation itself. To take one recent example, Emmott's book "10 Billion" reviews the evidence and concludes despairingly that "I think we're $f^{\star \star \star \star} d$ " (Emmott, 2013, p. 196). Taken at face value, many more people will be tempted to adopt this conclusion, as the severity of the situation strikes home in a variety of concrete ways. On present evidence, this may well produce new waves of depression and avoidance (Riedy, 2013). On the other hand, it is possible to see this same outlook as providing new or renewed sources of motivation. After all, it is often forgotten that notions of a "great crash" are really little more than "do nothing" business-as-usual futures that greatly understate human and social capabilities. The whole point of moving from a collapse/crash/breakdown discourse to one characterised by notions 
of "descent" is that this recognises, and brings into play, a range of factors that are disregarded in more fatalistic or downbeat accounts.

Broadly speaking, collapse narratives tend to be regarded as - but don't necessarily have to be - disempowering (Polak, 1961). For many people, they seem to displace the "locus of agency" somewhere "out there" in other places and contexts beyond us and, hence, out of reach. Yet this is little more than an unconscious reflection of the worldviews involved. There are clearly other options. Within an expanded worldview, such futures can just as easily strengthen the motivation to change. As Riedy has pointed out, far more work is needed on this crucial issue and I'll return to it below. Overall, we've reached the point where the motivating power of positive and negative images of futures need be developed and deployed more widely.

Descent narratives and pathways are obviously preferable. For a start, they are more nourishing and directly helpful. They provide a context of support for interior development, the exercise of human autonomy and choice and the creation of much-needed social innovations. A great deal hangs on our collective ability to make these shifts and, fortunately, there is no shortage of resources available. For example, work by writers such as J.M. Greer and James Howard Kunstler can be used to set the scene, as it were, by exploring various dimensions of descent. They are complemented and extended by later and perhaps more applied contributions by people such as Holmgren, Fry, Hopkins, Jackson, Watson and Freeman and Floyd (Greer, 2013; Kunstler, 2005; Holmgren, 2009; Fry, 2009; Hopkins, 2009; Jackson, 2011; Watson and Freeman, 2012; Floyd, 2013). Immersion in material of this kind accelerates the process of moving from denial and despair towards qualified optimism and the active evaluation of appropriate actions and strategies. This type of focused immersion in quality materials may perhaps qualify as a new and valuable form of futures literacy.

At the very end of their book. The Burning Question, the authors make the following observation that I've used at the beginning of this paper. They write that "the key question of our era is which complex system will tip first, the climate or the human response. It's the ultimate high-stakes race" (Berners-Lee and Clark, 2013, p. 199). This again implies that we need insights from human and social systems every much as from ecological and planetary systems. In other words, phenomena from each quadrant domain should be equally taken into account. Yet in scanning and sampling a wide range of materials on different aspects of the global emergency it's clear that the upper left, or interior individual, quadrant domain has perhaps received the least attention of all. While some observers have acknowledged that human psychology in general has a role, remarkably few appear to have taken the next steps. Responses to the global emergency arise from within the personal and social life worlds of people, the specific traits, worldviews, contexts and values that serve to motivate or inhibit them. Regardless of the specific method or approach being used, these key factors need to be drawn more fully into the picture.

The hostile and dismissive responses to progressive initiatives that were examined earlier have quite obviously served to impede our overall ability to deal with the global emergency. Therefore, it is useful to ask what the following have in common and then contrast these responses with other, more promising, options.

- the cynicism and privileging of self in promoting "doubt is our product";

- the "denial machine" that also places self, money and its own small part of the human economy above all other considerations;

- the attempt to "take down" those working to understand global change and to destroy or marginalise projects such as the LtG;

- the imperatives of "carbon interests" that continue to encourage an entirely unsustainable and increasingly risky process of global addiction to fossil fuels that, in principle, are becoming too dangerous to use. 
- the continued widespread recourse to future-discounting and the prevalence of short-term thinking and valuation when short-, medium- and long-term issues clearly require serious and sustained attention;

- the mocking dismissal of forward thinking per se and the lack of concern for the destruction of ecosystems shown by conservative politics and news media;

- the continued pursuit of economic growth as a universal panacea when several global limits have already been exceeded (Rockstrom, 2009); and

- the continued disruption of natural systems that result from the above (Ehrich and Ehrlich, 2013);

These phenomena are so prevalent that they can appear "normal." At the same time, they suggest a kind of default collective profile. Simply using the criteria outlined above, these attributes and practices appear to:

- arise from ego- and socio-centric outlooks that serve to privilege "me, us and now";

- proceed from a conventional level of complexity (with forays into post-conventional when it comes to, e.g. financial innovation and marketing); which also means that "the present" (however understood) is seen as more monolithic and, in a sense, authoritative than it actually is;

- express a range of values from "red" to "orange," none of which provides a substantive basis from which to resolve the global emergency; and

- Mainly address the lower right (exterior collective) domain of reality, with some instrumental focus in the lower left (for social influence) and upper right (to persuade and control).

This brief overview by no means exhausts the available criteria for adjudicating these concerns. As it stands, however, it reveals some of the core elements of an instrumentalist, denialist and self-aggrandising syndrome that, even now, remains embedded at the highest levels of corporate, financial and political life. This combination of human and cultural traits may well therefore constitute the most significant threat to our collective futures.

If the shift from collapse to descent narratives is to be achieved, and multiple but demanding pathways of descent credibly pursued thereafter, then we will need to find ways to bring people and organisations forward and out of these self-defeating states of being. Social support will be needed not only to finance solar panels and re-localised economic structures but also to help many, many people to face reality and regard the global emergency less as a cause for depression and disengagement, than as a reason to aspire to more comprehensive worldviews and more sustaining values. This is core necessity of our time and, properly understood, it could bring forward the long-awaited "renaissance" in futures studies and applied foresight.

\section{The role of exemplars}

A limitation of this account, thus far, is that it tends towards the abstract and schematic. Therefore, it is useful to consider what can be learned from three individuals who arguably provide us with "worked examples" deriving from other outlooks and values that contrast markedly with those outlined above. In the BWCH, I considered how Mohammad Yunus, James Hanson and Joanna Macy each contribute towards a more sustaining and sustainable outlook (Slaughter, 2010, Chapter 11). Each can be considered an exemplar in and for our present time. Their individual achievements can be widely emulated by others, thereby opening out social options and potentials that would otherwise remain hidden. The core relevance of the issue here is that each one has:

[. . . ] moved from passive acceptance of the reality around them to a set of active responses that directly address specific and deeply felt concerns. Moreover, each of them has also inspired 
similar responses on the part of many other people, leading them to discover their own deeper insights and connect these with actions of their own.

This pattern is not uncommon for social innovators. Moreover, their experience and example has profound social implications:

First, the experience of some sort of dysfunction in the world; second, the personal awakening that leads to the activation or development of new or renewed capabilities; and third, taking this work from individual vision to social implementation, thereby opening the door for others (Slaughter, 2010, p. 179).

In essence, they demonstrate in practice some of the constructive capabilities that will be required in the years ahead if descent pathways are to credibly emerge. Some of the key conclusions that I drew from each person's lived experience are as follows:

- Muhammad Yunus

- If the values and motivations are appropriate, it is possible to take on some of the most powerful organisations in the world and win;

- if you work at responding to peoples' real needs, there's a better chance of success;

- $\quad$ if you devote yourself wholeheartedly and selflessly to a task that is inherently worth doing, the energy required is available in full measure; and

- anyone can change the world, if they go about it in the right way.

- James Hansen

- We need to act now to rein in $\mathrm{CO}_{2}$ emissions to preserve the well-being of planet Earth, its life forms and future generations;

- although our knowledge of the Earth system is incomplete, the direction of climate change is clear and we have sufficient knowledge to act;

- we cannot rely on established institutions to make the necessary changes in values, economies, energy usage and ways of life; and

- direct action, especially by the young, has become necessary, especially to wake up decision-makers and to phase out the burning of coal.

- Joanna Macy

- It's essential to feel gratitude for the gift of life;

- There's no need to be afraid of the trauma and pain of the world - they arise from our interconnections with it and each other;

- we should dare to vision and then get involved with the "great turning"; and

- if we "act our age," i.e. draw on the full authority of the 15 billion years of our existence, then we have access to hidden strengths (Slaughter, 2010, pp. 178-9).

The contrasts between these responses and those cited earlier are not merely dramatic but instructive and, I would argue, profoundly inspiring. Gone is the exclusive focus on one or two reality domains. Gone is the focus on self and the sidelining of others, both present and future. Absent also is the reliance on limited value sets. Gone finally, is the drive for power, material wealth and domination over others. Instead, we see more encompassing values, post conventional worldviews that are, indeed, capable of "seeing with fresh eyes" and, overall, broader views of reality that acknowledge phenomena in all of the quadrant domains. In summary, three conclusions follow:

1. The seeds of many solutions appear to be grounded in the left-hand quadrant domains. That is, in enhanced human capacities, more encompassing worldviews and values that support world-centric outlooks. 
2. One of the most powerful and significant shifts that, in principle, is available to virtually anyone, is that from conventional thinking (taking perceived reality as more "real" and "finished" than it actually is) to post-conventional thinking (seeing things as constructed, i.e. more "open" and subject to revision and change).

3. While low-energy, more local and self-sufficient, lifestyles are becoming default assumptions, the viability of such arrangements will depend very much on the developmental capacities of the individuals within them and the necessary social validation and support that these will require. These factors, therefore, need to be brought more clearly into focus and supported by purposeful mainstream social and institutional strategies.

Some important caveats are necessary here. First, in pursuing an argument about enhanced human and social development we should beware of the "growth to goodness" fallacy. That is, while the mere fact of human and social development demonstrates the potential for enhanced capacities across the board we must acknowledge that those very capacities can be used for good or ill. Second, the tendency to privilege normative aspects of integral accounts of human development needs to be resisted since this many-stranded topic is itself one that is open and evolving. Then, as Floyd points out, the use of hierarchical models of increasing complexity do not necessarily provide the best or only way to appreciate "advanced human functioning." In brief: we ought not to rely on a "rising psycho-developmental tide to lift all boats" (Floyd, 2013; Krafcik, 2011).

Taking both of the left-hand quadrants of the integral model seriously (the interior individual and the interior collective) means that we are attending both to human and social factors. Social contexts (including media, institutions, communities, disciplines and systems of government) exert major influences on what people can know as well as what they can do. It is important to be aware of the nature and consequences of these influences. For example, Walsh reminds us that societies "embody not only much wisdom but also foolishness." Moreover:

The ratio of wisdom to foolishness - what we might call the sagacity: stupidity ratio - may well be one of the most important cultural factors determining individual and collective well-being, as well as how much cultures support or suppress the search for wisdom [. . .] Most importantly, the sagacity: stupidity ratio will likely determine the fate of societies, our species, and our planet (Walsh, 2012, p. 5).

Equally (despite the elusiveness of the concepts and practices through which it is enabled), notions of wisdom have much to offer in this context. Walsh writes that:

The enormity and variety of threats confronting humankind are all too obvious, and responding to them will require all our resources, both inner and outer. One of the most fundamental and important responses will be to better understand and develop human virtues: qualities and capacities such as ethics, care, compassion and wisdom. For the remarkable thing about our current global crisis is that most of them can be traced to a lack of just these qualities (Walsh, 2012, p. 1).

There's a strong link here with Wendell Bell's call for a code of ethics for futures and foresight practitioners, and the Association of Professional Futurists (APF) has shown considerable interest in the area (Bell, 1997). But it's also fair to say that such a code has yet to become a widespread norm within the field. There is, however, evidence that this many-stranded profession is beginning to respond to the challenges outlined here. Therefore, I will outline a few relevant examples.

\section{New and renewed agendas for futures studies and applied foresight}

There are few or no simple answers when it comes to supporting some of the positive shifts outlined above. What we already know, however, brings greater clarity to some of the capacities that are, or can be, enacted by human beings within their social contexts. 
Broadly speaking, the latter serve to create and sustain or, alternatively, to destroy and discourage what might be called the "mind and spirit spaces" that are required to confront the global emergency. Clearly, a great deal of serious work to be done in this area. Floyd suggests that we need to focus on:

- the means by which we decide collectively on the particular human attributes [ . . ] that we regard as most worthy of promoting, encouraging and valorising within our societies; and

- how we might organise our societies in such ways that individuals' development tends towards the ways of being that we value (Floyd, 2013, pp. 226-7).

Recent work by Chris Riedy is also useful here. He has reviewed a sample of "collapse/ descent" literature and derived what he calls "seven possible signs of awakening," as follows:

1. widespread availability of realistic information about the possible futures humanity faces, so that embracing reality is possible (i.e. futures literacy);

2. evidence that values are shifting towards an expanded ecological self or becoming more attuned to the planetary scale, gradually or rapidly;

3. evidence that activist responses are becoming more prevalent than nihilistic or fundamentalist responses;

4. signs of collective agency and cooperation, such as the emergence of a global citizen's movement;

5. signs of engaged dialogue out of which such movements can grow;

6. emergence of new forms of distributed leadership; and

7. the existence of inspiring visions that motivate action. (Riedy, 2013, p. 180).

He poses some key questions about whether or not apocalyptic images of futures are a necessary condition of "awakening"; also, under what conditions, such confrontations might lead toward positive outcomes. He then concludes by suggesting the following actions:

- a broader review of the relevant literature in part to identify "additional criteria" and "additional signals";

- practitioners could "work to strengthen the signals of awakening" through "prospective work that broadens values, supports activism, promotes cooperation and dialogue, builds the capacity for leadership and offers inspiring visions"; and

- an attempt is needed to "make connections between the diverse movements" involved in the process and, from these to fashion a much broader "awakening movement" (Riedy, 2013, p. 181).

Some innovative paradigm breaking developments have been reported by Kurki and Wilenius who studied a number of Silicon Valley start-up companies. They found that some of them were making serious efforts to establish small businesses on a basis that directly contributed to, and supported, some necessary and promising social innovations (Kurki and Wilinius, 2013, draft paper for Futures). Other initiatives are emerging through the work of people who are consciously responding to the new conditions. One of the most interesting is a developing conversation from the southern Europe and Mediterranean region around the subject of "de-growth" (Cattaneo et al., 2012). This appears to have real intellectual clout and deserves wider attention. It may be one of the most promising developments for some time (Sekulova et al., 2013). Mishan's earlier work on the notion of a "steady state economy" has also gained traction and is being pursued by a new generation of players (Czech, 2013). Mishan's 1991 book on the subject defined such an economy as: 
One with constant stocks of people and artifacts, maintained at some desired, sufficient levels by low rates of maintenance 'throughput', that is, by the lowest feasible flows of matter and energy from the first stage of consumption to the last stage of consumption (Daly, 1991, p 17).

We are, however, a very long way, indeed, from such core statements of intention to achieving viable forms of implementation. Trainer reminded us of this in a paper called "De-growth: do you realise what it means?" in which he lays out some of the very demanding conditions such an economy would entail (Trainer, 2012).

Beyond this, a number of other disciplines are beginning to develop their own responses. One example is Krumdieck's fascinating account of "transition engineering" (Krumdieck, 2013). Another is a comparative survey carried out by Wiseman and Edwards (2012) on "post-carbon pathways." It cannot be denied that the global assault on the environment in pursuit of growth and development continues apace, especially in places such as the Amazon where in-depth understanding of the global consequences is both well-known and accepted (Watts and Viera, 2014). Yet even here there are signs of progress that in time may well reinforce each other. For example, Zolli and Healy (2012) provide welcome examples of the practicality of resilience practices in Third World Environments. At the same time, and half a world away, Higgins (2012) proposes a new "law of ecocide" that would bring serious sanctions to bear on the most destructive practices internationally.

A recent piece by Miller \& Hopkins on the "climate after growth" is as directly useful as anything l've seen in a futures/foresight context. It identifies the growth imperative "as the underlying cause of the climate crisis" and seeks to facilitate "community resilience" as the primary action goal. To this end, they identify what they term "the new normal" in three dimensions: the new energy normal, the new climate normal and the new economic normal (Miller and Hopkins, 2013, pp. 3-11). Their paper concludes with the following summarising statement:

Instead of trying to help bail out the sinking ship of globalized, fossil-fueled, inequitable, growth-based economy, the environmental community should build a different vessel. By growing community resilience, environmentalists can offer an alternative to the "growth at all costs" story, one in which taking control of our basic needs locally has multiple benefits: creating new enterprises and meaningful work; increasing well-being rather than GDP; reducing greenhouse gas emissions and dependence on fossil fuels; addressing social and economic inequities; and building the social cohesion necessary to withstand periods of crisis; and perhaps most critically, showing a different way (Miller and Hopkins, 2013, p. 22.).

This is clearly a positive vision for the future that can contemplate disastrous futures and yet responds to that diminished outlook decisively and constructively. While it is, to some considerable extent, driven by an appreciation of danger and dysfunction, it is also very clearly informed by some of the qualities and capabilities discussed here. These include a post-conventional outlook in which change is possible, values that reach out beyond the individual ego and worldviews that can encompass global dynamics situated within a range of coherent forward views. The expressed goal of "finding a different way" would, I imagine, resonate fully within the hearts and minds of many futures workers.

\section{Conclusion}

When the first Russian and American rockets placed people and objects in orbit, and then later took men to the moon and back, the dominant response was an all-too-typical triumphalism - "look at how powerful we are"; "look at how we have conquered space." How empty those vastly over-stated sentiments appear now. Few seem to have realised that those pillars of flame represented an orgy of overconsumption of scarce energy resources, a sign of the entropic trap towards which humanity is now sliding. Each such launch was, in fact, made possible not only by engineering skill and cultural hubris. It burned literally millions of years of stored solar energy in mere moments. This is the real tragedy and disaster of late industrialism: it simply did not allow us to know - or care to know - what was being done in our name or why. It promoted the view that humans - or

PAGE 544 foresight $\mid$ VOL. 16 NO. 62014 
rather a small segment of temporarily affluent humans - were able to venture way beyond cultural and environmental limits without penalty or cost. Brian Aldiss' witty observation that science fiction was basically about "hubris clobbered by nemesis" may well be the leitmotiv of our age.

This same willed blindness also meant that Earth Day 1970, and so many similar events and initiatives that followed, were little more than empty charades, token moves in a symbolic game played against vastly more powerful social, cultural and economic forces. So, rather paying closer attention to the health, the vital statistics of planet Earth, the uncompromisingly anthropocentric forces driving the economic system continued unabated across the entire planet. What is truly amazing is that, despite everything, this very same charade continues to this day. Were that not the case, then events like the 2013 "March for the Reef" that occurred in Brisbane (and other locations) would be unnecessary. As it stands, the apparently "urgent" need to further develop industrial resources in North Queensland apparently trumps the need to maintain priceless natural assets such as the ancient reef communities that lie offshore. In the current ways of conventional thinking, this is portrayed as "development vs conservation," and we already know which side will prevail. We could, of course, do all this quite differently. But there's a great deal of letting go, uncluttering and reframing to achieve first.

For example, all across the developed world there are legions of highly educated and reasonably intelligent people in high-tech office towers hunched 24/7 over desks equipped with computer screens of great power and capability. Yet all this technical capacity is applied in a strangely one-sided way. Some of these people are trading stocks and shares. Others are trading derivatives and other "unreal" entities within a bubble of vast complexity and even greater fragility. As noted above, some are cheating the system in the most egregious and indefensible ways. In an alternative world, there are still a large number of such people hunched in front of multi-coloured data-driven screens. However, far fewer of them are monitoring the human economy per se. Rather, a resurgent "World watch" community is checking rainfall in the Himalayas, temperatures in the polar regions and a million data points elsewhere. The state of the global system is being actively monitored and communicated. In this world, it is clearly understood that the indices of the global life-support system are of vastly greater significance than the latest figures on the stock and currency exchange markets.

At least three points emerge from the above. First, we need to move on from the somewhat restricted maps of reality that were handed down to us from earlier times. While respecting those who created them, we now need to carry out our own work. That is, to expand the map to include all four reality domains, along with more expansive worldviews and a much deeper appreciation for the pivotal role of values. Second, and with this in mind, we need to pay a great deal more attention to supporting interior change and development in the face of very challenging futures. How do we make full use of the attractions of "compelling visions of desirable futures" while also drawing on the potential ability of Dystopian visions to help us wake up and act without becoming fearful and overwhelmed? How, too, can we open up and demystify the underlying dynamic of the IPAT formula (Impact = Population $\times$ Affluence $\times$ Technology) so that more people understand what it means and feel empowered to respond?

Third, vastly improved forms of professional and institutional support are required to support the kinds of efforts discussed here. Part of that may be a globally connected network of loFs tasked with assembling the bits and pieces, the fragments of promising work and socially positive innovations that can contribute toward intelligent public policy. Since the universities have shown so little interest in this work, these new-generation organisations will most likely be lean, adaptive, free standing and independently funded. Finally, we need to find new ways to support these diverse contributions. This can and should occur through the emergence of a mainstream social project to reclaim the future from the fate that otherwise awaits humanity. It is a project that unites grassroots initiatives 
with those undertaken by leading players, organisations and institutions (Slaughter, 2012b; Riedy, 2013; Liu, 2013).

Descent pathways leading towards survival - and even prosperity - in a world worth living in cannot be fully pre-defined in advance. They will emerge, as the necessary human and social efforts are devoted to understanding and creating them. They will also differ in many respects from country to country and culture to culture. This is quite obviously not merely the responsibility of futurists/foresight practitioners or middle-class would-be social innovators. The task of crafting descent pathways is one that concerns everyone. It, therefore, requires mainstream social validation and unstinting public support. When you really think about it, what is there to lose?

\section{References}

Ahmed, N. (2014), "NASA-funded study: industrial civilisation headed for 'irreversible collapse?' Earth Insight", The Guardian, 14 March, available at: www.theguardian.com/environment/earth-insight/201 4/mar/14/nasa-civilisation-irreversible-collapse-study-scientists (accessed 15 March 2014).

AtKisson, A. (1999), Believing Cassandra, Scribe, Melbourne.

Bageant, J. (2011), Walzing at the Doomsday Ball, Scribe, Melbourne.

Bardi, U. (2011), The Limits to Growth Revisited, Springer, New York, NY.

Beck, D. and Cowan (1996), C. Spiral Dynamics, Blackwell, MA.

Bell (1997), Foundations of Futures Studies, Human Science for a New Era, Transaction, New Brunswick, Vol. 1.

Berners-Lee, M. and Clark, D. (2013), The Burning Question, Profile Books, London.

Carter, J. (1977), "Address to the nation on energy", available at: www.youtube.com/watch?v=-tPeP pMxJaA\&feature $=$ related

Carter, J. (1979), "Crisis of confidence speech", available at: www.youtube.com/watch?v=1IIRVy7oZ 58\&feature $=$ related

Cattaneo, C., D'Alisa, G., Kallias, G. and Zografos, C. (Eds) (2012), "Policy, democracy and degrowth", Futures, Vol. 44 No. 6.

Czech, B. (2013), Supply Shock: Economic Growth at the Crossroads and the Steady State Solution, New Society Publishers, Gabriola Island, BC.

Daly, H. (1991), Steady-State Economics, Island Press, Washington, DC.

Diamond, J. (1998), Guns, Germs, and Steel, Vintage, London.

Ehrich, P. and Ehrlich, A. (2013), "Can a collapse of global civilisation be avoided?", Proceedings of the Royal Society B - Biological Sciences, p. 280, available at: http://rspb.royalsocietypublishing.org/ content/280/1754/20122845.full.pdf (accessed 9 September 2013).

Emmott, S. (2013), Ten Billion, Allen Lane, London.

Esbjorn-Hargens, S. (2009), "An overview of integral theory", available at: http://integrallife.com/node/ 37539

Flannery, T. (1994), The Future Eaters, Reed, Chatswood, Sydney.

Floyd, J. (2013), "Energy, complexity and interior development in civilisational renewal", On the Horizon, Vol. 21 No. 3.

Fry, T. (2009), Design Futuring: Sustainability, Ethics and New Practice, UNSW Press, New South Wales, Sydney.

Glenny, M. (2009), McMafia: Seriously Organised Crime, Vintage, London.

Goldenberg, S. (2013), "Secret funding helped build vast network of climate denial think tanks", The Guardian, 14 February, available at: www.guardian.co.uk/environment/2013/feb/14/funding-climatechange-denial-thinktanks-network (accessed 16 February 2013).

Greer, J.M. (2013), Not the Future We Ordered, Karnak Books, London.

Hamilton, C. (2005), Affluenza, Allen \& Unwin, Sydney.

PAGE 546 foresight $\mid$ VOL. 16 NO. 62014 
Hamilton, C. (2010), Requiem for a Species, Allen \& Unwin, Crows Nest, Sydney.

Hansen, J. (2012), "Game over for climate", New York Times, 10 May, available at: www.nytimes.com/ 2012/05/10/opinion/game-over-for-the-climate.html (accessed 12 May 2012).

Hiatt, S. (Ed) (2007), A Game as Old as Empire, Berrett-Koehler, San Francisco, CA.

Higgins, P. (2012), Earth is Our Business: Changing the Rules of the Game, Shepheard-Walwyn, London.

Holmes, J. (2013), "From great moral challenge to indifference", Sydney Morning Herald, 4 September.

Holmgren, D. (2009), Future Scenarios, Chelsea Green, VT.

Hopkins, R. (2009), The Transition Handbook, Chelsea Green, VT.

Howard, R. (2013), "Kiwis' 2060 forecast seen as a load of hot air", The Weekend Australian, 13-14 July, p. 26.

Jackson, T. (2011), Prosperity Without Growth, Earthscan, London.

Jamail, D. (2013), "The coming 'instant planetary emergency'", The Nation, 17 December, available at: www.thenation.com/article/177614/coming-instant-planetary-emergency\# (accessed 3 January 2014).

Kilachand, N. (2012), "Death of a Mumbai river will not trouble many”, The Australian, 27 August, p. 10.

Krafcik, D. (2011), "Words from the wise: a qualitative and quantitative study of nominated exemplars of wisdom", Ph.D. thesis, Institute of Transpersonal Psychology, Palo Alto, CA.

Krumdieck, S. (2013), "Transition engineering: planning and building the sustainable world", The Futurist, Vol. 47 No. 4, available at: www.wfs.org/futurist/2013-issues-futurist/july-august-2013-vol-47no-4/transition-engineering-planning-and-build (accessed 19 June 2013).

Kunstler, J.H. (2005), The Long Emergency, Atlantic Books, London.

Kurki, S. and Wilinius, M. (2013), "Organisations and the sixth wave: are ethics transforming our economies in the coming decades?", Futures, available at: http://dx.doi.org/10.1016/j.futures.2014.0 9.001 (accessed 16 September 2014).

Lanier, J. (2013), Who Owns the Future?, Penguin, London.

Liu, J. (2013), "Green Gold (documentary video)", available at: www.dailykos.com/story/2013/04/18/ 1198024/-Introduction-to-Agroecology-Green-Gold-The-Source-of-Wealth-is-are-the-Functional-E cosystems\#

McKibben, B. (2013), "How Australian coal is causing global damage: false profits", The Monthly 90, June, Melbourne, available at: www.themonthly.com.au/issue/2013/june/1370181600/bill-mckibben/ how-australian-coal-causing-global-damage (accessed 6 June 2013).

Meadows, D.L, Meadows, D.L. and Randers, J. (1992), Beyond the Limits: Global Collapse or a Sustainable Future?, Earthscan, London.

Meadows, D.H., Meadows, D.L., Randers, J. and Behrens, W.W. (1972), The Limits to Growth, Universe Books, New York, NY.

Meadows, D.H., Randers, J. and Meadows, D.L. (2005), Limits to Growth - 30 Year Update, Earthscan, London.

Miller, A. and Hopkins, R. (2013), Climate After Growth, Post Carbon Institute, Santa Rosa, CA and Transition Network, Totnes, Devon, available at: www.postcarbon.org/report/1882095-climate-aftergrowth (accessed 20 October 2013).

Mishan (1969), The Costs of Economic Growth, Pelican, London.

Mumford, L. (1971), The Pentagon of Power, Weidenfeld and Nicholson, London.

National Intelligence Council (NIC) (2013), Global Trends 2030: Alternative Worlds, US Government, Washington, DC.

Oreskes, N. and Conway, E. (2011), Merchants of Doubt, Bloomsbury, London.

Pearse, G. McKnight, D. and Burton, B. (2013), Big Coal: Australia's Dirtiest Habit, New South Books, Sydney.

Perkins, J. (2004), Confessions of an Economic Hit Man, Berrett-Koehler, San Francisco, CA. 
Polak, F. (1961), The Image of the Future, translated by Boulding, E., Oceana, New York, NY.

Poyourow, J. (2014), "Economic descent, hopefully with skillful means", available at: http://transitionus. org/blog/economic-descent-hopefully-skillful-means (accessed 12 February 2014).

Randers, J. (2012), 2052: A Global Forecast for the Next Forty Years, Chelsea Green, VT.

Riedy, C. (2013), "Waking up in the twenty-first century", On The Horizon, Vol. 21 No. 3, pp. 174-186.

Rockstrom, J. (2009), "A safe operating space for humanity”, Nature, Vol. 461, pp. 472-476.

Scranton, R. (2013), "Learning how to die in the anthropocene, Opinionator", New York Times, 10 November, available at: http://opinionator.blogs.nytimes.com/2013/11/10/learning-how-to-die-in-theanthropocene/?_r=0\&pagewanted=print (accessed 14 February 2014).

Scruton, R. (2013), The Uses of Pessimism and the Danger of False Hope, OUP, Oxford.

Sekulova, F., Kallis, G., Rodriguez-Labajos, B. and Schneider, F. (2012), "Degrowth: from theory to practice", Journal of Cleaner Production, Vol. 38, pp. 1-6.

Simons, C. (2013), The Devouring Dragon: How China's Rise Threatens the Natural World, Scribe, Melbourne.

Slaughter, R. (2010), The Biggest Wake-Up Call in History, Foresight International, Brisbane.

Slaughter, R. (2012a), To See With Fresh Eyes: Integral Futures and the Global Emergency, Foresight International, Brisbane.

Slaughter, R. (2012b), "Sense making, futures work and the global emergency", Foresight, Vol. 14 No. 5, pp. 418-431.

Slaughter, R. (2013a), "Defending the future: introductory overview of a special issue of On the Horizon on responses to The Biggest Wake-Up Call in History", On the Horizon, Vol. 21 No. 3, pp. 168-173.

Slaughter, R. (2013b), Review of Entropia: Life Beyond Industrial Civilisation, op cit. Foresight, Vol. 16 No. 3, pp. 289-291.

Slaughter, R. (2013c), "Time to get real: a critique of Global Trends 2030", World Future Review, World Future Society, Bethesda MD.

Smith, A. (2014), "What just happened?", The Guardian, 7 June.

Spratt, D. (2014), "The real budgetary emergency and the myth of 'burnable carbon'", available at: www.climatecodered.org/2014/05/the-real-budgetary-emergency-burnable.html?utm_source= feedburner\&utm_medium =email\&utm_campaign =Feed\%3A +ClimateCodeRed $+\% 28$ climate + code+red\%29 (accessed 23 May 2014).

Steffen, W., Sanderson, R.A., Tyson, P.D., Jäger, J., Matson, P.A., Moore, B. III, Oldfield, F., Richardson, K., Schellnhuber, H.J., Turner, B.L. and Wasson, R.J. (Eds) (2004), Global Change and the Earth System: A Planet Under Pressure, Springer, Berlin \& New York, NY.

Taylor, A. (2014), The People's Platform: Taking Back Power and Culture in the Digital Age, Fourth Estate, London.

Trainer, T. (2012), "De-growth: do you realise what it means?", Futures, Vol. 44 No. 6, pp. 590-599.

Turner, G. (2008/2009), "A comparison of the limits to growth with thirty years of reality", Socio-Economics and the Environment in Discussion, CSIRO Working Paper Series, Canberra.

Urry, J. (2013), Societies Beyond Oil: Oil Dregs and Social Futures, Zed Books, London.

Walsh, R. (2012), "Wisdom: an integral view", Journal of Integral Theory and Practice, Vol. 7 No. 1 , pp. 1-21.

Watson and Freeman, K. (2012), Futurevision, Scribe, Melbourne.

Watts, J. and Viera, K. (2014), "Dying to save the Amazon", The Observer, 15 June.

Weisman, A. (2013), Countdown: Our Last, Best Hope for a Future on Earth?, Little Brown, London.

Wilber, K. (2000), Integral Psychology, Shambhala, Boston.

Wilkinson, R. and Pickett, K. (2009), The Spirit Level, Allen Lane, London.

Wilson, E.O. (2002), The Future of Life, Abacus, New York, NY. 
Wiseman, J. and Edwards, T. (2012), "Post carbon pathways: reviewing post carbon economy transition strategies", Centre for Policy Development \& Sustainable Society Institute, Melbourne, available at: http://cpd.org.au/2012/03/post-carbon-pathways/ (2 October 2012).

Wood, A. (2006), "The fraud of global warming", The Australian, 19 July.

Zolli, A. and Healy, A.M. (2012), Resilience, Headline, London.

\section{Further reading}

Alexander, S. (2013), Entropia: Life Beyond Industrial Civilisation, Simplicity Institute, Melbourne.

Ballard, D. (2013), "New UK government publications on an integral approach to climate change", available at: http://integrallife.com/integral-post/new-uk-government-publications-integral-approachclimate-change (accessed 3 August 2013)

Beck, U. (2000), World Risk Society, Polity Press, Cambridge.

Daly, H. (1971), Steady-State Economics, 2nd ed., Long Island Press, Washington, DC.

Diamond, J. (2005), Collapse: How Societies Choose to Succeed or Fail, Viking, New York, NY.

Greer, J.M. (2008), The Long Descent, New Society Publishers, Gabriola Island, BC.

Hines, A. and Bishop, P. (2006), Thinking About the Future: Guidelines for Strategic Foresight, Social Technologies, MA.

Lynas, M. (2008), Six Degrees: Our Future on a Hotter Planet, Harper Perennial, London.

Mishan, E.J. (1969), The Costs of Economic Growth, Pelican Books, London.

Schumacher, E.F. (1974), Small is Beautiful, Sphere Books, London.

Slaughter, R. (2009), "Beyond the threshold: using climate change literature to support climate change response", Journal of Integral Theory and Practice, Vol. 4 No. 4. pp 27-46, available at: http:// richardslaughter.com.au/wp-content/uploads/2010/02/RS_Beyond_Threshold_Final.pdf

\section{Corresponding author}

Richard A. Slaughter can be contacted at: rslaughter@ozemail.com.au

To purchase reprints of this article please e-mail: reprints@emeraldinsight.com Or visit our web site for further details: www.emeraldinsight.com/reprints 